\title{
Terapi Bekam Sebagai Stimulasi Imun Tubuh Menghadapi Covid-19
}

\author{
${ }^{1 *}$ Marimin, ${ }^{2}$ Abdul Muhaimin, ${ }^{3}$ Rasfiuddin Sabaruddin, ${ }^{4}$ Tanwir, ${ }^{5}$ Ridwan Faroji \\ Sekolah Tinggi Ilmu Ekonomi Hidayatullah, Depok, Indonesia \\ *marimin@stiehidayatullah.ac.id
}

\begin{abstract}
Abstrak
Tujuan Pengabdian Kepada Masyarakat (PKM) Mahasiswa ini adalah untuk mengadakan program bakti sosial kepada masyarakat terkait pengobatan terpai bekam. Bekam adalah terapi pengobatan tradisional menggunakan gelas atau tabung yang ditelungkupkan pada bagian permukaan kulit tertentu agar menimbulkan bendungan lokal. Menurut ilmu kedokteran, terdapat teori keseimbangan dimana alam semesta dan isinya, termasuk organ tubuh manusia, selalu berada dalam keadaan seimbang. Terapi bekam membantu menjaga keseimbangan tersebut. Masyarakat yang diduga positif Covid-19 akibat imun daya tahannya yang lemah sehingga mudah tertular berbagai virus. Alasan tersebutlah yang mendasari kegiatan bakti sosial terapi bekam dalam upaya menstimulasi imun tubuh. Penulis melakukan pengumpulan data melalui kuesioner serta studi terhadap dua buku. Dengan program bakti sosial kesehatan terapi bekam ini, penulis berharap masyarakat mendapatkan kesehatan prima.
\end{abstract}

Kata Kunci: Terapi Bekam, Covid-19

\begin{abstract}
The purpose of this Student Community Service (PKM) is to hold a social service program for the community related to cupping therapy. Cupping is a traditional medical therapy using a glass or tube that is inverted on certain parts of the skin surface to create a local dam. According to medical science, there is a balance theory in which the universe and its contents, including human organs, are always in a state of balance. Cupping therapy helps maintain this balance. People who are suspected of being positive for Covid-19 are due to their weak immune resistance, so they are easily infected with various viruses. This reason underlies the social service activities of cupping therapy in an effort to stimulate the body's immune system. The author collects data through questionnaires and studies of two books. With this cupping therapy health social service program, the author hopes that the community will get excellent health.
\end{abstract}

Keywords: Cupping Therapy, Covid-19

\section{PENDAHULUAN}

Awal tahun 2020 dunia digegerkan dengan berita mewabahnya penyakit yang disebut corona virus disease 19 (COVID-19) yang mulai merebak di Wuhan, Cina. Pandemi tersebut kemudian menyebar di berbagai negara, termasuk negara Indonesia juga tak luput dari dampak pandemi ini, masyarakat yang diduga positif Covid-19 dikarenakan akibat imun daya tahannya yang lemah sehingga mudah tertular berbagai virus. Hal tersebut menjadi dilema tersendiri bagi masyarakat apalagi orang yang memiliki penyakit lebih rentan terhadap serangan infeksi virus. Kondisi stress (pikiran) juga cenderung meningkatkan kemungkinan individu untuk terkena penyakit infeksi.

Di zaman canggih yang serba ada seperti saat ini, gaya hidup masyarakat tentu sudah berubah. Konsumsi yang serba instan, serta cara bekerja yang semakin dimudahkan dengan teknologi, memberi dampak tersendiri terhadap tingkat kesehatan masyarakat. Salah satu dampaknya adalah risiko kesehatan yang semakin meningkat. Hal ini menyebabkan masyarakat melakukan berbagai cara untuk menjaga kesehatan agar tidak mudah jatuh sakit, terlebih lagi saat ini masyarakat tengah dikhawatirkan dengan pandemi virus Covid-19. Salah satu upaya yang dapat dilakukan adalah dengan melakukan bekam. 
Oleh karena itu pada PKM kali ini, kami bertujuan untuk mengadakan program bakti sosial dengan terapi bekam kepada masyarakat agar dapat menjalankan sunnah pengobatan nabi untuk menperoleh kesembuhan dan dapat meningkatkan serta menstimulasi imun tubuh dalam menangkal berbagai virus yang ada selama pandemi.

\section{METODE}

Metode pelaksanaan pengabdian kepada masyarakat ini diawali dengan melakukan peninjauan lapangan dan koordinasi dengan mitra. Metode kegiatan ini adalah mendatangi dan menawarkan bakti sosial dan diskusi pentingnya terapi bekam selama pandemi bagi para masyarakat yang berada di lingkungan pondok pesantren Hidayatullah Depok.
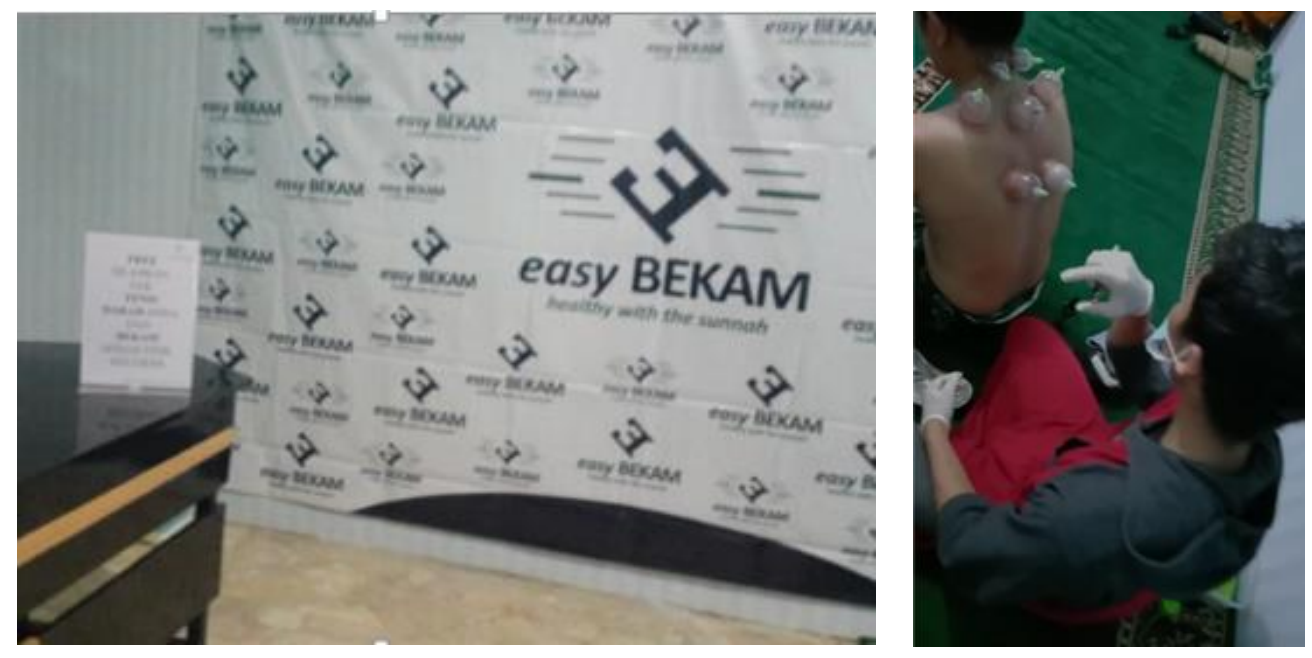

Gambar 1. Pelaksanaan Kegiatan PKM dilokasi

\section{HASIL DAN PEMBAHASAN}

Berdasarkan hasil dan pembahasan yang ada. Dapat ditarik kesimpulan mengenai pengaruh terapi bekam terhadap stimulasi imun tubuh, yaitu pengaruh bekam terhadap peningkatan stimulasi imun tubuh manusia yang tidak lepas dari proses terapi bekam itu sendiri di mana pada terapi tersebut, darah yang memiliki peran sebagai pengantar sari-sari makanan yang kotor disedot sehingga darah akan menjadi bersih.

Selain itu, hilangnya sumbatan pada darah brupa oksidan juga akan memperlancar aliran makanan yang dibawa oleh darah menuju ke seluruh bagian tubuh. Dengan demikian, perbaikan sel dapat terlaksana dan rasa sakit yang diderita akan segera berkurang sehingga berpengaruh dalam peningkatan imun tubuh, selain itu ada efek khususnya berupa rasa tenang, dalam diri manusia.

Adapun faktor yang mendukung keberhasilan terapi bekam adalah faktor medis dan faktor non medis. Pada faktor medis, keberhasilan tersebut disebabkan adanya aliran darah yang lancar akan menjadikan sari makanan dapat diterima dengan baik dan tepat waktu oleh seluruh bagian tubuh sehingga produksi hormon sebagai pusat pengendalian tubuh manusia akan kembali "sehat". Sedangkan faktor non medis berkaitan erat dengan keberadaan do'a yang berfungsi sebagai penenang jiwa sekaligus "jaminan" terkabulnya segala usaha penyembuhan manusia oleh Allah SWT yang mempunyai kekuasaan atas segala kekuatan kehidupan manusia di dunia. 


\section{PENUTUP}

\section{KESIMPULAN}

Hasil penelitian ini menegaskan bahwa terapi bekam merupakan salah satu terapi yang memiliki kelebihan tersendiri dibandingkan dengan terapi pengobatan alternative lain. Kelebihan yang pertama adalah adanya jaminan halal berdasarkan anjuran Nabi Muhammad kepada umat Islam untuk menjadikan terapi bekam sebagai terapi pengobatan. Oleh karena itu, menurut penulis, perlu adanya pengembangan, baik berwujud sosialisasi pemanfaatan sebagai terapi pengobatan maupun pelatihan keilmuannya. Sosialisasi pemanfaatan dan pelatihan terapi bekam secara tidak langsung juga menjadi bagian dari ibadah umat Islam, yakni sebagai perwujudan pelaksanaan sunnah Rasulullah Saw.

\section{SARAN}

Setelah melakukan pengamatan dalam proses penelitian, penulis menemukan beberapa hal yang dapat menjadi titik tolak saran yang akan penulis buat. Pertama, program kegiatan bakti sosial pengobatan tradisional baik secara khusus, dan umumnya perlu mengadakan sosialisasi terapi bekam sebagai alat penyembuhan bagi penyakit manusia karena bekam bukan hanya terapi kesembuhan penyakit namun juga menjadi terapi keimanan seseorang. Kedua, bagi lembagalembaga yang memiliki hubungan dengan kesehatan manusia, baik lembaga kesehatan maupun kependidikan, perlu mengadakan pelatihan bekam berkaitan dengan kesehatan manusia, terlebih yang berkaitan dengan kesehatan fisik dan mental manusia.

\section{DAFTAR PUSTAKA}

Cahyono, S. (2008). Gaya hidup dan penyakit modern. Jakarta: Kanisius.

Carlson, E. (2008). The lucky few: Between the greatest generation and the baby boom. Berlin: Springer Science \& Business Media.

Eka, P. D., et al. (2020). Manajemen Keuangan Untuk Meningkatkan Perekonomian Keluarga Kampung Serua Poncol Tangerang Selatan. BAKTIMAS: Jurnal Pengabdian pada Masyarakat, 2(2), 109-113.

Erlangga, H., et al. (2020). Pengembangan Kapasitas Usaha Kecil Kerupuk Kentang Di Kampung Ciawitali Desa Warnasari Kecamatan Pangalengan Kabupaten Bandung. Jurnal Pengabdian Tri Bhakti, 102-109.

Griffin, E. A. (2003). A First Look at Communication Theory. Singapura: McGraw-Hill.

Howe, N., \& Strauss, W. (2000). Millennials rising: The next great generation. New York: Vintage Books.

James A. Christenson \& Jerry W. Robinson, Jr Ames, Community Development In Perspective: Lowa State University Pres, 1989, hal 215)

Kotler, P., Roberto, N., \& Lee, N. (2002). Social marketing: Improving the quality of life. California: SAGE Publications.

Landa, R. (2013). Graphic design solutions (Edisi ke-5). Boston, MA: Cengage Learning.

Larson, C. U. (1992). Persuation: Reception and responsibility. California: Wardsworth Publishing Company

McQuail, D. \& Windahl, S. (1993). Communication models for the study of mass communications 2nd edition. Robert C. Hornick (Ed.). London: Routledge.

Muhtadi. (2018). Pemberdayaan Masyarakat Berbasis Masjid Terhadap Perubahan Perilaku Penerima Manfaat Program. Dialog, 41(2), 167-179.

Paeno, P., et al. (2020). Pemanfaatan Sampah Plastik Untuk Kerajinan Rumah Tangga Taman Belajar Kreatif Mekar Sari. BAKTIMAS: Jurnal Pengabdian pada Masyarakat, 2(1), 57-61.

Pusat Data dan Informasi Kementerian Kesehatan RI. (2014). InfoDATIN: Hipertensi. Diunduh dari 
http://www.depkes.go.id/resources/download/pusdatin/infodatin/infodatinhipertensi.p df

Putra, IGS., et al, (2020). Dampak Pelatihan Manajemen Kreatif Industri Peci Menuju Sentra Peci Di Desa Langonsari Kecamatan Pameungpeuk Kabupaten Bandung. Coopetition:Jurnal Ilmiah Manajemen. 11(1)

Rawi, R. D. P., et al. (2019). Pelatihan Pembuatan Keripik Pisang Sebagai Sarana Peluang Bisnis Dan Kreatifitas Mahasiswa Fakultas Ekonomi Universitas Muhammadiyah Sorong. Abdimas: Papua Journal of Community Service, 1(2), 24-30.

Ridho, A. A. (2019). Bekam Sinergi: Rahasia Sinergi Pengobatan Nabi, Medis Modern, \& Traditional Chinese Medicine. Solo: Aqwamedika.

Samsul Munir Amin. (2009). Ilmu Dakwah. Jakarta: Amzah. 183-184)

Sebastian, Y. (2016). Generasi langgas millenials Indonesia. Jakarta: GagasMedia.

Tohirin. (2011). Dasar-dasar Metode Penelitian Pendekatan Praktis. Pekanbaru. h. 40.

Umar, W. A. (2008). Sembuh dengan Satu Titik. Solo: Al-Qowam Publishing.

Venus, A. (2018). Manajemen kampanye: Panduan teoritis dan praktis mengefektifkan kampanye komunikasi. Bandung: Simbiosa Rekata Media.

Yusuf, A. M. (2014). Metode Penelitian: Kuantitatif, Kualitatif, dan Penelitian Gabungan. Jakarta: Prenamedia Group 